\title{
The proteolytic activity of the HtrA (DegP) protein from Escherichia coli at low temperatures
}

Correspondence

Joanna Skorko-Glonek

glonek@biotech.ug.gda.pl

Received 12 May 2008

Revised 27 August 2008

Accepted 28 August 2008

\author{
Joanna Skorko-Glonek, Anna Sobiecka-Szkatula, Joanna Narkiewicz \\ and Barbara Lipinska
}

University of Gdansk, Department of Biochemistry, Kładki 24, 80-822 Gdansk, Poland

\section{INTRODUCTION}

Escherichia coli cells have to cope with various environmental conditions during their life cycle. In their primary habitat (the gastrointestinal tracts of mammals and birds) they might be exposed to heat shock, oxidative stress or the presence of toxins. However, it has been estimated that only half of the E. coli population inhabits the bodies of its hosts; the other half resides in the external environment - water, sediment and soil (Savageau, 1983; Souza et al., 2002). In the external habitat bacteria must cope with variable temperature, $\mathrm{pH}$, low nutrient availability and a wide range of toxic compounds usually present in polluted environments. The exposure of cells to stressful conditions damages various cellular components, including proteins. Proteins that have lost their native conformation may aggregate or interact with inappropriate partners. To prevent these detrimental effects, cells induce sophisticated defence systems, whose role is to suppress the aggregation and refold the denatured proteins, or to degrade the irreversibly damaged proteins. These functions are carried out by molecular chaperones and proteases, respectively (Schlieker et al., 2002). The HtrA protein has been shown to combine both activities: that of a chaperone and that of a protease (Clausen et al., 2002). It is a periplasmic serine protease indispensable for the survival of $E$. coli at elevated temperatures and under certain conditions of oxidative stress (Lipinska et al., 1989; Skorko-Glonek et al., 1999). The expression of the htrA gene is upregulated in response to various stress condi-

Abbreviations: AP, alkaline phosphatase; $\triangle$ CysHtrA, HtrAC57AC69A; IAA, iodoacetamide. tions, including heat shock, oxidative stress and the presence of reducing agents (Skorko-Glonek et al., 2003). This protein plays a very important role in the extracytoplasmic protein quality control system, as it is a major periplasmic protease responsible for degrading damaged or abnormal polypeptides within the cellular envelope (Clausen et al., 2002). The proteolytic activity of HtrA was shown to be temperature dependent. In the in vitro assay HtrA cleaved its substrate ( $\beta$-casein) efficiently at temperatures above $30{ }^{\circ} \mathrm{C}$. Maximum activity was observed at temperatures around $45^{\circ} \mathrm{C}$, which corresponded well with the important role of this protease under heat-shock conditions (Skorko-Glonek et al., 1995; Spiess et al., 1999). At temperatures below $28{ }^{\circ} \mathrm{C}$ the proteolytic activity was regarded as negligible and it was believed that the protein then plays the function of a chaperone (Spiess et al., 1999).

The lack of proteolytic activity of HtrA at low temperatures can be explained by the crystal structure of this protein (Krojer et al., 2002). The protein is composed of three functionally distinct domains: a proteolytic domain (residues 1-259) and two PDZ domains (PDZ1, residues 260-358; PDZ2, residues 359-448), which are involved in protein-protein interactions. The native molecule was shown to be a hexamer. It is formed by association of two trimeric rings, stabilized by interactions between the PDZ domains. Additionally, long LA loops protrude into the opposing subunits and wind around each other, forming pillars connecting the two rings. At low temperatures the catalytic site is in an inactive conformation and is occluded by three interacting loops: L1, L2 and LA (using chymotrypsin nomenclature). The LA loop comes from the opposing monomer (Krojer et al., 2002). Within the LA 
loop there is a disulfide bridge, important for maintaining protein stability (Skorko-Glonek et al., 2003). In the recent work of Krojer et al. (2008) it was shown that during the activation process the HtrA hexamer disassembles to trimers, which subsequently form 12-mers or 24-mers. This rearrangement requires disruption of the loop trio LA-L1-L2, in particular the removal of the LA loop from the opposing HtrA subunit. It has been proposed that these structural changes can be induced by an increase of temperature and/or by allosteric activation by specific peptides (Jones et al., 2002; Krojer et al., 2008).

As mentioned above, E. coli populations residing in external environments might be exposed to stressful conditions at temperatures much lower than the physiological $37{ }^{\circ} \mathrm{C}$. We expect that in such situations the proteolytic activity of HtrA is required for bacteria to survive. In this work we examined the proteolytic activity of HtrA in cells subjected to stressful conditions at low temperatures. We demonstrated that in conditions disturbing disulfide bond formation, HtrA showed proteolytic activity at temperatures as low as $20{ }^{\circ} \mathrm{C}$ and efficiently degraded reduced alkaline phosphatase both in vivo and in vitro. This ability was especially pronounced in the case of a cysteineless HtrA mutant unable to form the intramolecular S-S bond ( $\Delta$ CysHtrA); thus we concluded that the reduction of HtrA's disulfide bridge may facilitate the activation of the protease.

\section{METHODS}

Materials. Alkaline phosphatase (AP) was from Fermentas. The antiAP polyclonal antibodies were from Chemikon. The anti-HtrA rabbit polyclonal antibodies were obtained in our laboratory by affinity chromatography using an immobilized HtrA protein as described by Skorko-Glonek et al. (2003). Immobilon-P, $0.45 \mu \mathrm{m}$ for immunoblotting, was obtained from Millipore. The Ni-NTA agarose was from Qiagen. The other chemicals were purchased from Sigma or Fluka and were of the highest quality.

Bacterial strains and growth conditions. The strains and plasmids used are listed in Table 1. Plasmid pCS13 was a generous gift from Professor M. Ehrmann. Strains KB1, KB3, KB5 and KB8 were constructed by bacteriophage $\mathrm{P} 1$ transduction of appropriate mutations from JCB817 or BL20.

Mutations C57A and C69A were introduced into the htrA gene by site-directed mutagenesis using Quick-Change (Stratagene) and their presence was verified by sequencing. The DNA sequencing was performed in the Institute of Biochemistry and Biophysics PAN, Warsaw, using the following primers: 5'-GCGAGGAAGCGGAAGAGCG-3', 5' -CCCCACCGCAGAGACAATCCCG-3'.

The E. coli strains were grown in LB (Luria-Bertani broth) medium, supplemented with an appropriate antibiotic when necessary. The growth of the bacteria was monitored by measuring the increase in $\mathrm{OD}_{595}$.

For AP activity studies, the overnight bacterial cultures were diluted in a low-phosphate medium (Munson \& Fall, 1978) supplemented with $0.1 \%$ amino acids (except cysteine and methionine) to obtain a final $\mathrm{OD}_{595}$ of $0.15-0.2$ and then grown for $2-4 \mathrm{~h}$. DTT sensitivity experiments were performed as described by Sardesai et al. (2003). The bacteria were plated onto LA (LB medium supplemented with $1.5 \%$, w/w, Bacto-agar) plates containing $7 \mathrm{mM}$ DTT and $1 \mathrm{mM}$ IPTG and incubated at $30{ }^{\circ} \mathrm{C}$ for $15 \mathrm{~h}$.

Determination of AP activity in bacterial extracts. Bacterial cells (1.2 ml culture, $\mathrm{OD}_{595}$ approx. 0.2-0.3) were resuspended in $0.45 \mathrm{M}$

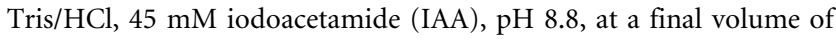
$4 \mathrm{ml}$. Following $10 \mathrm{~min}$ incubation at room temperature, $0.4 \mathrm{ml}$ of

Table 1. Bacterial strains and plasmids

\begin{tabular}{|c|c|c|}
\hline Strain or plasmid & Relevant characteristics & Reference or source \\
\hline \multicolumn{3}{|l|}{ Strains } \\
\hline B178 & W3110 galE sup ${ }^{+}$ & Our collection \\
\hline BL20 & W3110 htrA63 gale sup ${ }^{+}$ & Lipinska et al. (1989) \\
\hline BL21DE3 & $\mathrm{F}^{-} \operatorname{ompT} h s d S_{\mathrm{B}}\left(\mathrm{r}_{\mathrm{B}}^{-} \mathrm{m}_{\mathrm{B}}^{-}\right) g a l d c m$ & Novagen \\
\hline MG1655 & Wild-type E. coli & Our collection \\
\hline JCB 816 & MC1000 phoR zig12:: Tn10 (malF-lacZ102) & $\begin{array}{l}\text { J. C. A. Bardwell, University of Michigan, } \\
\text { Ann Arbor }\end{array}$ \\
\hline JCB817 & JCB $816 d s b A^{-}$ & J. C. A. Bardwell \\
\hline KB1 & $\mathrm{B} 178 d s b A$ & This work \\
\hline KB3 & B178htrAdsbA & This work \\
\hline KB5 & MG1655htrA & Skorko-Glonek et al. (2006) \\
\hline KB8 & MG1655htrAdsbA & Skorko-Glonek et al. (2006) \\
\hline \multicolumn{3}{|l|}{ Plasmids } \\
\hline pQE60 & T4 expression vector, C-terminal $6 \times$ histidine tag & Qiagen \\
\hline pJS17 & pQE60 derivative carrying $h t r A S 210 A$ gene & Skorko-Glonek et al. (2003) \\
\hline pJS18 & pQE60 derivative carrying the wild-type $h t r A$ gene & Skorko-Glonek et al. (2003) \\
\hline pAMS 3 & pQE60 derivative carrying $h$ trAC57AC69A gene & This work \\
\hline pAMS18 & pQE60 derivative carrying $h$ trAC57AC69AS210A gene & This work \\
\hline pCS13 & $\begin{array}{l}\text { pQE32 derivative carrying mals gene lacking sequence coding for signal } \\
\text { peptide, } \mathrm{N} \text {-terminal } 6 \times \text { histidine tag }\end{array}$ & Spiess et al. (1999) \\
\hline
\end{tabular}


$4 \mathrm{mg}$ 4-nitrophenyl phosphate (PNPP) $\mathrm{ml}^{-1}$ was added. The activity of AP was measured according to Munson \& Fall (1978).

Electrophoresis of proteins and Western blotting. Bacteria were grown to $\mathrm{OD}_{595}$ 0.4-0.6. To obtain equal amounts of cells we measured the $\mathrm{OD}_{595}$ of the bacteria and took an appropriate volume of culture according to the equation: $\left[800 / \mathrm{OD}_{595}\right] \times 400 \mu$ l. Cells were then centrifuged at $4000 \mathrm{~g}$ and resuspended in $80 \mu \mathrm{l} \mathrm{Laemmli}$ lysis buffer.

Proteins were analysed by SDS-PAGE as described by Laemmli (1970). Western blotting was performed as previously described (Oberfelder, 1993). The anti-AP antibodies were diluted $1: 2500$. Anti-HtrA rabbit polyclonal antibodies were diluted 1:125.

Determination of redox states. The in vivo redox state of AP and HtrA was assayed by trapping the free thiols with IAA according to a method adapted from Jakob et al. (1999) and Kishigami et al. (1995). Portions of $0.7 \mathrm{ml}$ of each culture were withdrawn and mixed with $0.2 \mathrm{ml}$ of $0.45 \mathrm{M}$ IAA in $100 \mathrm{mM}$ Tris, $10 \mathrm{mM}$ EDTA, $\mathrm{pH}$ 9.2. The samples were incubated at $37^{\circ} \mathrm{C}$ for $2 \mathrm{~min}$ and the reaction was stopped with trichloroacetic acid (TCA) $(10 \%, \mathrm{v} / \mathrm{v}$, final concentration). Prior to the addition of TCA, lysozyme was added to a final concentration of $0.2 \mathrm{mg} \mathrm{ml}^{-1}$ to improve the efficiency of the precipitation. All samples were incubated overnight at $-20{ }^{\circ} \mathrm{C}$, and then centrifuged for $30 \mathrm{~min}$ at $4{ }^{\circ} \mathrm{C}$ and $20000 \mathrm{~g}$. The pellets were resuspended in a non-reducing Laemmli lysis buffer supplemented with $20 \mathrm{mM}$ IAA.

Protein purification. The His-tagged wild-type HtrA protein was purified from strain BL20(pJS18). Bacteria were grown in LB medium supplemented with ampicillin $\left(75 \mu \mathrm{g} \mathrm{ml}^{-1}\right)$ to $\mathrm{OD}_{595} 0.5-0.6$. HtrA protein synthesis was induced by the addition of IPTG to $1 \mathrm{mM}$. After $2 \mathrm{~h}$ the cells were harvested, resuspended in a buffer containing $50 \mathrm{mM}$ Tris/ $\mathrm{HCl}(\mathrm{pH} 8.0), 1 \mathrm{mM}$ EDTA, $10 \%(\mathrm{w} / \mathrm{v})$ sucrose, and frozen to $-70{ }^{\circ} \mathrm{C}$. The subsequent steps involving cell lysis and ionexchange chromatography on DEAE-cellulose were performed as described previously (Skorko-Glonek et al., 1995). Fractions of HtrA eluted from the DEAE-cellulose were pooled, $1 \mathrm{M}$ imidazole ( $\mathrm{pH} 8.0$ ) was added to $10 \mathrm{mM}$ final concentration, and $\mathrm{NaCl}$ to a concentration of $300 \mathrm{mM}$. Then the HtrA solution was dialysed against a buffer containing $25 \mathrm{mM}$ HEPES (pH 8.0), $300 \mathrm{mM} \mathrm{NaCl}, 10 \mathrm{mM}$ imidazole, $10 \%(\mathrm{v} / \mathrm{v})$ glycerol, and applied onto $1 \mathrm{ml} \mathrm{Ni-NTA}$ resin. $\mathrm{HtrA}$ was eluted at an imidazole concentration of $100 \mathrm{mM}$.

MalS was purified from strain BL21DE3(pCS13) according to the method described by Spiess et al. (1999). The purity ( $>95 \%)$ of the $\mathrm{HtrA}$ and MalS preparations was checked by SDS-PAGE, staining with Coomassie brilliant blue.

HtrA activity assay. Preparation of chemically denatured AP was performed as described by Akiyama et al. (1992). AP (final solution of $0.5 \mathrm{mg} \mathrm{ml}^{-1}$ ) was incubated overnight at $37^{\circ} \mathrm{C}$ in a buffer containing $6 \mathrm{M}$ urea, $0.12 \mathrm{M} \mathrm{DTT}, 1 \mathrm{mM} \mathrm{MgCl}_{2}, 25 \%$ (v/v) glycerol, $50 \mathrm{mM}$ $\mathrm{KCl}, 0.5 \mathrm{mM} \mathrm{MgSO}_{4}, 2 \mathrm{mM}$ EDTA and $50 \mathrm{mM}$ Tris/HCl, $\mathrm{pH}$ 8.0. MalS was purified under denaturing conditions and stored in buffer containing $8 \mathrm{M}$ urea, $100 \mathrm{mM}$ sodium phosphate, $\mathrm{pH}$ 7.0.

Wild-type HtrA $(0.8 \mu \mathrm{g})$ was incubated with $1.5 \mu \mathrm{g}$ reduced denatured $\mathrm{AP}$ in $25 \mathrm{mM}$ Tris $/ \mathrm{HCl}, \mathrm{pH} 8.0$ at a final volume of $100 \mu \mathrm{l}$ at 25 or $20{ }^{\circ} \mathrm{C}$. For the MalS degradation assay wild-type HtrA $(0.8 \mu \mathrm{g})$ was incubated with $1.5 \mu \mathrm{g}$ reduced denatured MalS in $25 \mathrm{mM}$ Tris/HCl, $2 \mathrm{mM}$ DTT, $\mathrm{pH} 8.0$ at a final volume of $100 \mu \mathrm{l}$ at $20{ }^{\circ} \mathrm{C}$. The reactions were terminated by addition of Laemmli lysis buffer and immediate freezing at $-20{ }^{\circ} \mathrm{C}$. The samples were then resolved by $10 \%$ SDS-PAGE and the gels stained with Coomassie brilliant blue. The electrophoretograms were analysed densitometrically using 1DScan EX (Scanalytics Inc.).
RESULTS

\section{Phenotypes of htrAdsbA double-mutant $E$. coli strains}

To study the role of the HtrA protein at low temperatures we chose the folding stress caused by the improper formation of disulfide bonds in extracytoplasmic proteins. The DsbA/DsbB oxidoreductase system is responsible for the introduction of the $\mathrm{S}-\mathrm{S}$ bonds into the cell envelope proteins; thus strains lacking any component of this system are impaired in disulfide bond formation. Therefore we introduced to the E. coli $h t r A$ strain an additional $d s b A$ mutation and examined the phenotypes of the htrA, $d s b A$ and htrAdsbA mutants in two different genetic E. coli backgrounds: MG1655 and B178. At low temperatures $\left(30{ }^{\circ} \mathrm{C}\right)$ all strains grew well in rich LA or LB media; only the double-mutant strain htrAdsbA showed a slightly decreased growth rate (data not shown). It is known that the $d s b A$ mutant exhibits increased sensitivity towards reducing agents. The presence of $10 \mathrm{mM}$ DTT in solid LA medium is lethal for this mutant, whereas the wild-type strains can still grow (Sardesai et al., 2003). This finding prompted us to test if lower concentrations of DTT, which still allowed strains with a single $d s b$ mutation to grow, would have a stronger effect on the strains with the double $h t r A d s b A$ mutation. Indeed, we observed a significantly increased sensitivity to $7 \mathrm{mM}$ DTT in the htrAdsbA strain when compared to the $d s b A$ strain. However, we must note that the strength of this effect varied according to the different genetic backgrounds of the mutant strains. The strongest differences in bacterial growth and survival in the presence of $7 \mathrm{mM}$ DTT were observed for the E. coli B178 derivatives. As shown in Fig. 1, the growth of the doublemutant $h t r A d s b A$ strain was dramatically inhibited (100fold at least). It should be mentioned that growth of all the E. coli B178 derivatives tested was affected by the presence of the reducing agent, including the wild-type strain. Their colonies were much smaller than those formed on the LA plates without DTT (not shown). In addition, the survival rate of the strains with single mutations, including $h t r A$, was lower by at least one order of magnitude than in the case of the wild-type parental strain (Fig. 1).

Our results showed that the $h t r A$ gene was very important for survival of the $d s b A$ mutant in the reducing environment. Since the experiment was carried out at a relatively low temperature $\left(30{ }^{\circ} \mathrm{C}\right)$, we asked the question whether the observed effect was due to the lack of chaperone activity of HtrA in the htrAdsbA double mutant. To answer this, we transformed the mutant strain $h t r A d s b A$ with a high-copy-number plasmid carrying the htrAS210A gene (plasmid pJS17), overexpressing the HtrAS210A protein, which lacks proteolytic activity but retains chaperone activity (Spiess et al., 1999). Indeed, the presence of HtrAS210A increased the survival rate of the tested $h t r A d s b A$ double-mutant bacteria; however, we did not observe a return to the parental $d s b$ phenotype. Their survival rate was at least 10 -fold lower and their colony size 


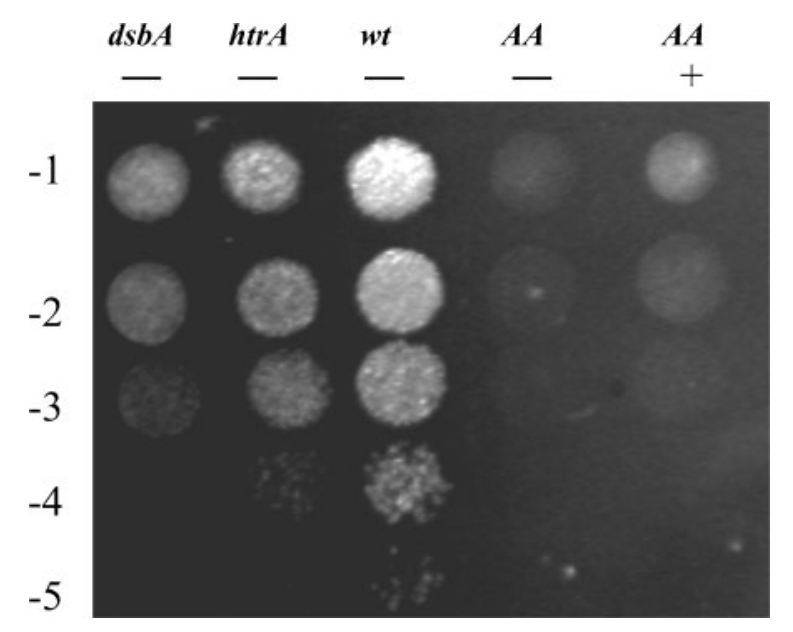

Fig. 1. DTT sensitivity of $E$. coli strains lacking the functional $h t r A$ gene. The figure shows the growth of a set of mutants derived from E. coli B178 (wild-type). Tenfold serial dilutions of exponentially growing cultures $(4 \mu \mathrm{l})$ were spotted on LA agar plates supplemented with $7 \mathrm{mM}$ DTT and incubated at $30{ }^{\circ} \mathrm{C}$ for $\sim 18 \mathrm{~h}$. The corresponding mutations are indicated at the top; AA stands for the $h t r A d s b A$ mutant. Symbols $(+)$ and $(-)$ indicate bacteria overproducing and not overproducing HtrAS210A from pJS17 plasmid, respectively. These data are representative; similar results were obtained in two other experiments.

was markedly smaller than in the case of the corresponding parental $d s b A$ strain (Fig. 1). The presence of a vector plasmid not expressing HtrAS210A did not cause any significant effects on the growth and survival of the B178htrAdsbA strain (not shown). Thus, the proteolytic activity of HtrA seems to play an important role in bacterial cells even at low temperatures, at which the chaperone function was proposed as being dominant.

\section{Synthesis of HtrA is elevated in the dsbA mutant strains}

The work of Hiniker \& Bardwell (2004) showed that the lack of DsbA in a cell results in decreased levels of certain periplasmic proteins, including HtrA. This finding contrasted with the results of Raina et al. (1995), who showed that expression from an $h t r A$ promoter was increased at least twofold in the $d s b A$ mutant when compared to the wild-type parental E. coli strain. To clarify doubts concerning the level of HtrA in $d s b A$ strains, we evaluated the content of HtrA in cell extracts using Western blotting. Our results are in agreement with the findings of Raina et al. (1995). As shown in Fig. 2, HtrA synthesis was markedly increased in the $d s b A$ strain. The ratio of HtrA in the $d s b A$ / wild-type strains was calculated based upon densitometry, the mean being $1.78 \pm 0.21$.

The disparity between our results and those of Hiniker \& Bardwell (2004) most probably resulted from differences in sample preparation. In our case, whole-cell extracts derived

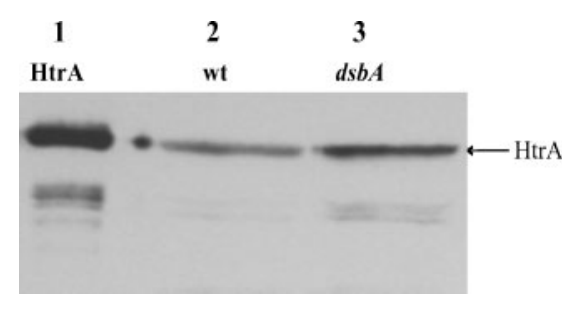

Fig. 2. The content of $\mathrm{HtrA}$ is elevated in the $d s b A$ mutant strain. E. coli $\mathrm{B} 178$ and E. coli $\mathrm{B} 178 d s b A$ cultures were grown at $30{ }^{\circ} \mathrm{C}$ in $\mathrm{LB}$ medium to $\mathrm{OD}_{595} 0.2-0.3$. Extracts of equal numbers of cells were resolved by SDS-PAGE (10\% gel) and subjected to Western analysis using anti-HtrA antibodies. The lanes show $\mathrm{HtrA}$ levels of the wild-type bacteria (lane 2) and the $d s b A$ mutant (lane 3). Lane 1 contains purified wild-type HtrA. The figure shows a representative example of three independent experiments.

from aliquots of bacterial cells were used, whereas Hiniker \& Bardwell (2004) analysed osmotic-shock extracts, containing soluble proteins. As we have previously reported (Skorko-Glonek et al., 1997), HtrA is attached to the inner membrane and in principle is not present in the soluble protein fraction. However, we observed that this binding was not very strong and various amounts of HtrA could be released from membranes, depending on the method of sample treatment (unpublished observation).

\section{HtrA degrades reduced AP at $30{ }^{\circ} \mathrm{C}$}

To better understand the function of the HtrA protein in cells deficient in the Dsb oxidase system, we focused on the properties of one particular periplasmic enzyme, AP. Native AP contains two disulfide bridges that play an important role in protein stability and activity (Akiyama et al., 1992). In agreement with earlier reports (Bardwell et al., 1991), we found that AP activity in the MG1655dsbA strain was drastically lower in comparison to the parental wild-type strain (approx. 20-fold) (data not shown). B178 derivatives were not used in this assay because they showed a much lower AP activity and in the double-mutant $h t r A d s b A$ strain AP activity was barely detectable.

We monitored the influence of HtrA presence on the activity and cellular content of AP. The expression of $h t r A$ genes from plasmids was induced by $0.1 \mathrm{mM}$ IPTG (regarded as a low level of HtrA in further experiments) or $1 \mathrm{mM}$ IPTG (a high level of HtrA). In strains possessing a functional DsbA/DsbB system, the presence of a high level of proteolytically active HtrA did not affect either the activity (Fig. 3a) or the amount of AP (Fig. 3c). However, in the htrAdsbA strain, AP activity was markedly lower (approx. 5-10-fold lower) in the presence than in the absence of HtrA (Fig. 3b, columns 5, 9). We assumed that this effect was due to the degradation of AP by HtrA, since the presence of proteolytically inactive HtrAS210A did not affect the activity of AP (Fig. 3b, columns 3, 8). This 
(a)

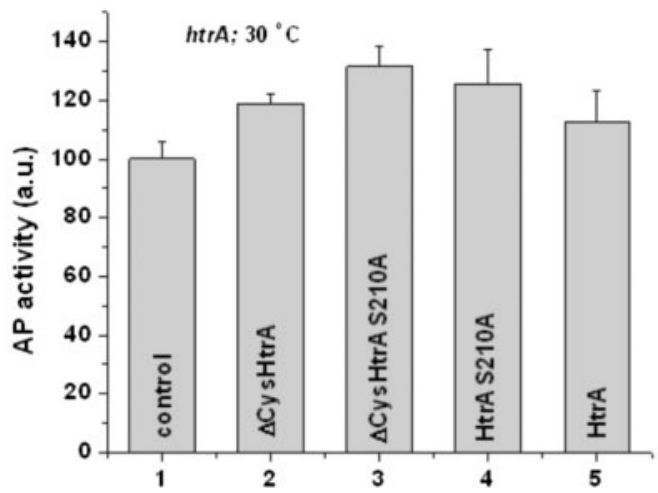

(c)

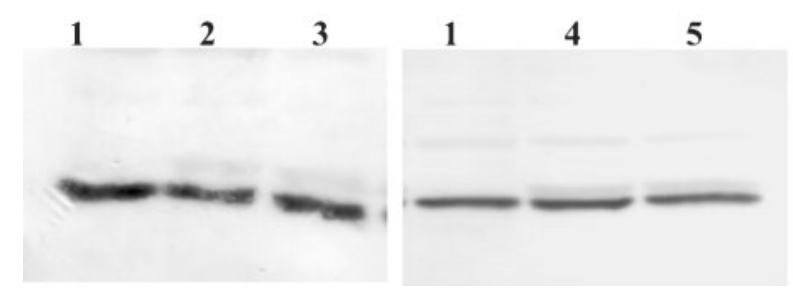

(b)

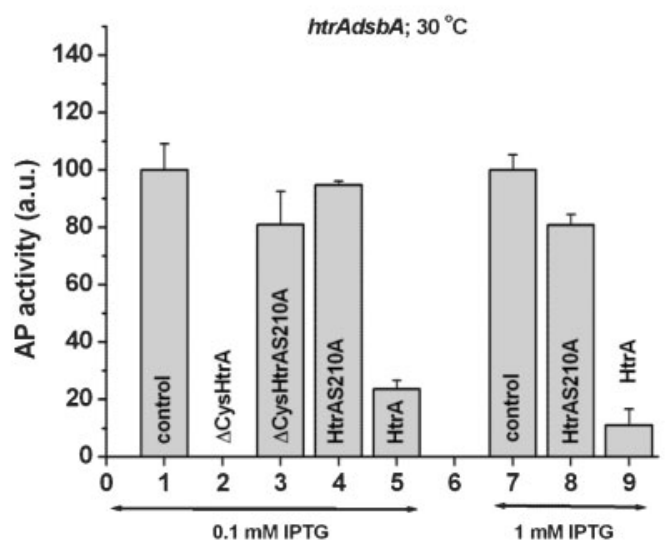

(d)

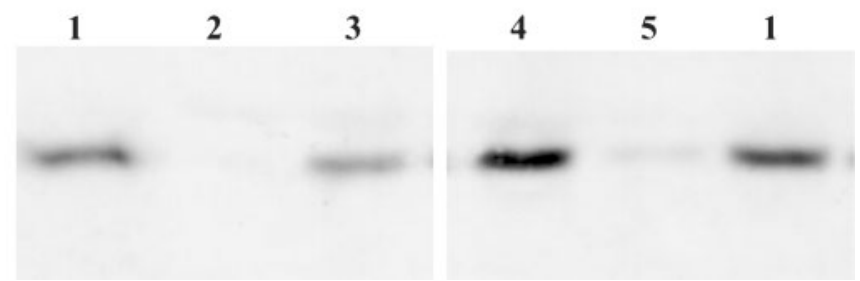

Fig. 3. Effect of the expression of various forms of $\mathrm{HtrA}$ on the activity and cellular content of $\mathrm{AP}$ at $30{ }^{\circ} \mathrm{C}$. (a, b) E. coli strains MG1655htrA (a) or MG1655htrAdsbA (b) carrying plasmid pJS17 (htrAS210A), pJS18 (htrA), pAMS18 ( $h$ trAC57AC69AS210A) or pAMS3 ( $h$ trAC57AC69A) were grown for $2 \mathrm{~h}$ in low-phosphate medium to induce the expression of the phoA operon and in the presence of $0.1 \mathrm{mM}$ or $1 \mathrm{M} \mathrm{IPTG}$ to express HtrA. The AP activity of each culture was measured as described in Methods. The values obtained were divided by the $\mathrm{OD}_{595}$ of each culture and then normalized to the value obtained for the control strain E. coli MG1655htrA (a) or MG1655htrAdsbA (b) and expressed in arbitrary units (a.u.). The values obtained for controls were set to 100 . The data correspond to means \pm SD of three different experiments. (c) Results of Western blotting, showing the cellular content of AP in MG1655htrA containing plasmid pAMS3 (lane 2), pAMS18 (lane 3), pJS17 (lane 4) or pJS18 (lane 5). Lane 1 represents control strain not producing HtrA. (d) AP levels in lysates of MG1655htrAdsbA carrying pAMS3 (lane 2), pAMS18 (lane 3), pJS17 (lane 4) or pJS18 (lane 5). The control strain without $\mathrm{HtrA}$ is shown in lane 1. For Western blotting analysis bacteria were grown in the presence of $0.1 \mathrm{mM}$ IPTG. Panels (c) and (d) show representative examples of the series of tests.

assumption was further confirmed by Western blotting analysis of cellular lysates. The levels of AP detected in $h t r A d s b A$ and $h t r A d s b A(\mathrm{pJS} 17)$ expressing HtrAS210A were very similar (Fig. $3 \mathrm{~d}$, lanes 4,1 ), whereas in the $h t r A d s b A(\mathrm{pJS} 18)$ strain expressing wild-type HtrA, AP was barely detectable (Fig. 3d, lane 5). No degradation products of AP were detected. AP activity measured in the medium fraction was less than $10 \%$. The levels of HtrA proteins in cellular lysates were comparable as judged by Western blotting analysis (not shown).

We have previously shown that in cells deprived of a functional DsbA/DsbB oxidoreductase system, HtrA is present mainly in a reduced form (Skorko-Glonek et al., 2006). Thus, we assumed that HtrA under experimental conditions was reduced and that fact could influence its proteolytic activity. To prove this we constructed a mutant
htrA gene in which the codons of Cys57 and Cys69 were replaced by Ala codons. The resulting gene product, $\Delta$ CysHtrA, was used as a control representing a completely reduced HtrA. As we expected, the effect of the presence of $\triangle \mathrm{CysHtrA}$ on AP was more pronounced: the activity of AP in the $h t r A d s b A$ (pAMS3) strain expressing $\Delta$ CysHtrA was undetectable, even at a low level of $\Delta$ CysHtrA (Fig. 3b, column 2).

\section{HtrA is proteolytically active at 25 and $20^{\circ} \mathrm{C}$}

The proteolytic activity of HtrA was regarded as negligible at temperatures below $28{ }^{\circ} \mathrm{C}$, as judged by in vitro assays using $\beta$-casein as a substrate (Spiess et al., 1999). Supposing that the reduction of HtrA activates this protein, we expected to observe an efficient cleavage of AP at temperatures lower than $28{ }^{\circ} \mathrm{C}$ in $E$. coli $d s b A$ strains. 
Indeed, at $25{ }^{\circ} \mathrm{C}$ the activity of AP was substantially lower (approx. twofold) in $h t r A d s b A$ cells expressing the wildtype HtrA from plasmid (Fig. 4a, column 5). In the presence of $\Delta$ CysHtrA, AP activity was much lower (approx. 10-fold) than in the control strain (Fig. 4a, column 2). These results correlated well with the Western blotting analysis of cellular extracts. The AP content of the htrAdsbA(pJS18) strain was markedly lower than in the control strain, whereas in the presence of $\Delta$ CysHtrA,
AP was undetectable (Fig. 4c, lanes 2, 5). The levels of wild-type HtrA and $\Delta$ CysHtrA in the cellular extracts were similar (Fig. 4e, lanes 2, 5). However, they were lower than the levels of the proteolytically inactive HtrAs (Fig. 4c, lanes 3, 4). This resulted most probably from the fact that HtrA undergoes autodegradation under reducing conditions. The autocleavage products are visible as additional bands below the main HtrA band (Fig. 4e, lanes 2, 5).

\section{Growth at $25^{\circ} \mathrm{C}$}

(a)

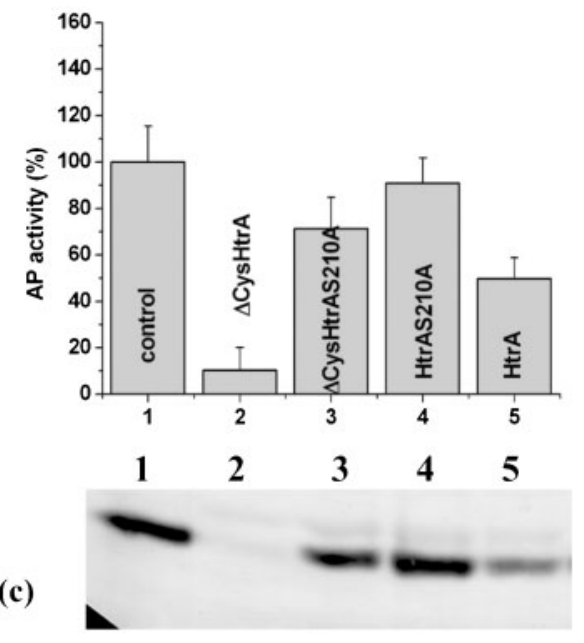

(e)

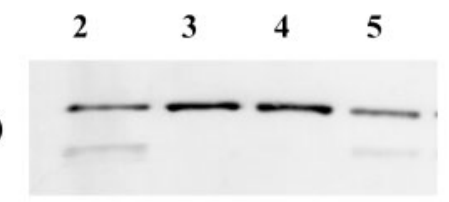

Growth at $20^{\circ} \mathrm{C}$

(b)
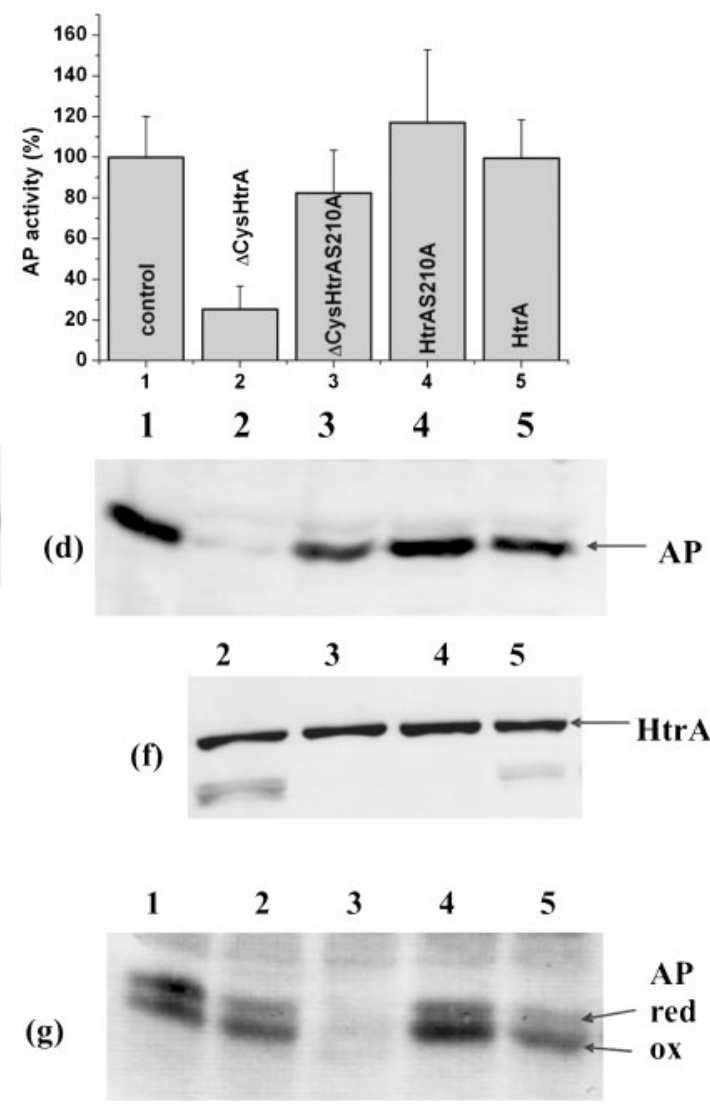

Fig. 4. Effect of the expression of various forms of $\mathrm{HtrA}$ on the activity and cellular content of $\mathrm{AP}$ at $25^{\circ} \mathrm{C}$ and $20{ }^{\circ} \mathrm{C}$. E. coli MG1655htrAdsbA containing plasmid pJS17 (htrAS210A), pJS18 ( $h$ trA), pAMS18 (htrAC57AC69AS210A) or pAMS3 ( $h$ trAC57AC69A) was grown at $25^{\circ} \mathrm{C}$ for $3 \mathrm{~h} \mathrm{(a)}$ or at $20^{\circ} \mathrm{C}$ for $4.5 \mathrm{~h} \mathrm{(b)}$ in a low-phosphate medium in the presence of $0.1 \mathrm{mM}$ IPTG. The values of the AP activity were obtained as described in the legend to Fig. 3. (c-g) Results of Western blotting. Cellular extracts of cultures used for the AP activity assay (see legend to a and b) were resolved by $10 \%$ SDS-PAGE and subjected to Western analysis using anti-AP or anti-HtrA antibodies. The analysis of the cellular content of AP in cultures grown at $25^{\circ} \mathrm{C}$ or $20^{\circ} \mathrm{C}$ expressing HtrA from plasmid pAMS3 (lane 2), pAMS18 (lane 3), pJS17 (lane 4) or pJS18 (lane 5) is shown in (c) and (d), respectively. The control strain without HtrA is shown in the lanes denoted 1. (e, f) Cellular content of HtrA expressed from plasmids pAMS3 (lane 2), pAMS18 (lane 3), pJS17 (lane 4) or pJS18 (lane 5) grown at $25^{\circ} \mathrm{C} \mathrm{(e)} \mathrm{or} 20{ }^{\circ} \mathrm{C}$ (f). (g) The redox state of $A P$ in bacteria expressing various forms of $\mathrm{Htr}$. Cellular extracts obtained from cultures grown at $20{ }^{\circ} \mathrm{C}$ were treated as described in Methods. Protein samples from equal numbers of cells were resolved by non-reducing SDS-PAGE $(10 \%)$ and subjected to Western blotting. The lanes show the AP level and redox state in bacteria expressing HtrA from plasmid pAMS18 (lane 2), pAMS3 (lane 3), pJS17 (lane 4) or pJS18 (lane 5) and in the control strain MG1655htrAdsbA (lane 1). Panels $(\mathrm{c})-(\mathrm{g})$ show representative examples of the series of tests (at least three for each panel). 
When the temperature of the cultures was further lowered to $20{ }^{\circ} \mathrm{C}$, the growth rates of bacteria were very slow; thus, we had to prolong the duration of the experiment to $4.5 \mathrm{~h}$ to obtain a detectable level of AP activity. As can be seen in Fig. 4b (column 2), in lysates containing $\triangle$ CysHtrA, AP activity was approximately fourfold lower compared to the control strain. Surprisingly, the presence of wild-type HtrA did not cause a decrease in AP activity (Fig. 4b, column 5). However, when we compared the AP content in cell lysates, it turned out that in the cells harbouring wild-type HtrA the level of AP was visibly lower than in the control $h t r A d s b A$ strain or in the presence of HtrAS210A (Fig. 4d). To explain the discrepancies between the activity and the amount of AP, we analysed the redox status of AP in the cellular lysates. It is known that in the $d s b A$ background, the formation of the S-S bonds in AP is disturbed and this in turn impairs the enzymic activity of AP. Therefore the fraction of active AP molecules in $d s b A$ mutants is much lower than in the wild-type strain. Fig. 4(g) shows the Western blotting analysis of the cellular lysates resolved under non-reducing conditions. In lane 1 , representing the control strain $h t r A d s b A$, two bands are visible. The upper band, corresponding to the reduced form of AP, is more intense than the lower one (oxidized AP); thus the majority of AP was in the non-native conformation. The reduced AP was also detected in lysates containing the proteolytically inactive forms of HtrA (lanes 2, 4). In lysates of htrAdsbA(pJS18), expressing wild-type HtrA, the presence of the reduced AP was hardly detectable (lane 5). Hence, the wild-type HtrA degraded the reduced non-native AP. Interestingly, the AP content in bacteria containing $\Delta$ CysHtrAS210A was also lower than in the control strain (lane 2). Since this mutant protein is proteolytically inactive, the decrease in AP could be due to the more efficient presentation of the substrate to other, as yet unknown, proteases.

We wondered why the wild-type HtrA was not as efficient as $\triangle$ CysHtrA in AP degradation. Due to the very low growth rates of cultures at low temperatures, the duration of the experiments was long $\left(3 \mathrm{~h}\right.$ and $4.5 \mathrm{~h}$ at 25 and $20{ }^{\circ} \mathrm{C}$, respectively). For this reason, we assumed that the wildtype HtrA might have undergone partial air oxidation and was less reduced compared to $\Delta \mathrm{CysHtrA}$. To check this possibility we analysed the redox status of HtrA in the htrAdsbA(pJS17) strain grown at $20{ }^{\circ} \mathrm{C}$. The results are shown in Fig. 5. The band corresponding to wild-type HtrA (lane 2) is 'hazy' and less shifted with respect to the band of the oxidized HtrA (lane 1) than $\Delta$ CysHtrA (lane $3)$. Therefore we conclude that wild-type HtrA was only partially reduced in our experiments.

\section{HtrA shows proteolytic activity at low temperatures in vitro}

To confirm the in vivo results, we purified the wild-type $\mathrm{HtrA}$ and examined its proteolytic activity at 25 and $20{ }^{\circ} \mathrm{C}$ using reduced, chemically denatured $\mathrm{AP}$ as a substrate. As

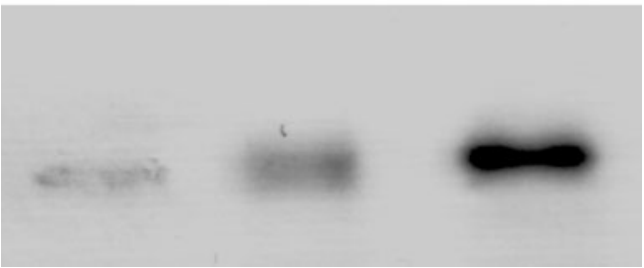

Fig. 5. Redox state of $\mathrm{HtrA}$ at $20^{\circ} \mathrm{C}$. E. coli MG1655htrA(pAMS3) bacteria, expressing cysteineless HtrAC57AC69A ( $\triangle$ CysHtrA), and E. coli MG1655htrAdsbA(pJS18), expressing wild-type $\mathrm{Htr} A$, were grown at $20^{\circ} \mathrm{C}$ as described in the legend to Fig. 4. Samples were prepared and resolved as described in Methods, and then subjected to Western blotting analysis using anti-HtrA antibodies. The lanes show purified oxidized HtrA (lane 1 ), wild-type HtrA expressed in the $h t r A d s b A$ mutant cells (lane 2), $\triangle \mathrm{CysH} \operatorname{trA}$ (lane 3 ). The figure shows a representative example of three independent experiments.

can be seen in Fig. 6, HtrA efficiently degraded the denatured AP at both temperatures and the majority of the substrate was cleaved within the time-course of the experiment (approx. $55 \%$ and $75 \%$ at $20{ }^{\circ} \mathrm{C}$ and $25{ }^{\circ} \mathrm{C}$, respectively). The other natural substrate of HtrA, periplasmic $\alpha$-amylase MalS, was even more efficiently degraded, and more than $80 \%$ of MalS was cleaved within 15 min of incubation at $20{ }^{\circ} \mathrm{C}$ (not shown). Therefore we conclude that HtrA is able to digest its natural substrates, $\mathrm{AP}$ and MalS, in a reducing environment at a temperature as low as $20^{\circ} \mathrm{C}$.

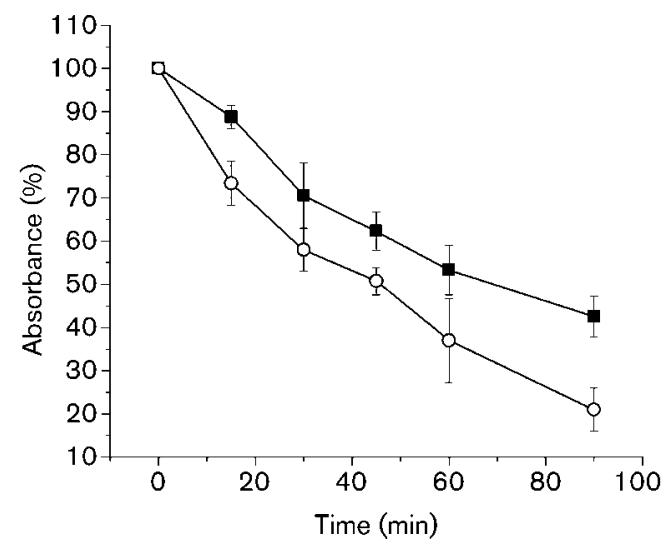

Fig. 6. HtrA degrades denatured AP at $25^{\circ} \mathrm{C}(\bigcirc)$ and $20{ }^{\circ} \mathrm{C}(\boldsymbol{\square})$ in vitro. The assay of AP degradation was performed as described (see Methods for details). In the graph the amount of the remaining non-degraded AP, expressed as percentage absorbance, is presented; $100 \%$ absorbance was the absorbance of the AP band at the beginning of the reaction (time ' $O$ '). Mean values of three independent experiments are shown. 


\section{DISCUSSION}

Stressful conditions produce damaged and unfolded proteins that are highly toxic to cells (Wickner et al., 1999). Therefore, E. coli populations that are exposed to various toxic compounds in polluted environments (such as detergents, oxidative or reducing agents, heavy metal ions) are in particular need of efficient defence systems. The periplasm of E. coli is particularly susceptible to stress factors due to the low selectivity of the outer membrane (Missiakas \& Raina, 1997). In the E. coli envelope, HtrA (DegP) is regarded as the key factor in protein quality control. HtrA has been previously proposed as acting as a chaperone at low temperatures (below $30{ }^{\circ} \mathrm{C}$ ), and as a protease at temperatures above $30{ }^{\circ} \mathrm{C}$ (Spiess et al., 1999). This temperature-dependent activity model is consistent with the strict requirement for the proteolytic activity of HtrA under heat-shock conditions. However, we wondered if the chaperone activity of HtrA is sufficient to protect bacterial cells from the consequences of chemical stress at low temperatures. To expand our knowledge about the functioning of HtrA, we examined the role of this protein in bacteria treated with a reducing agent (DTT). Proteins targeted to extracytoplasmic environments often require formation of proper disulfide bonds to attain their biologically active structures. In the presence of reducing agents these proteins are prone to denaturation and cells encounter folding stress. This phenomenon is especially pronounced in bacteria lacking the DsbA/DsbB oxidoreductase system, which catalyses the formation of S-S bonds within extracytoplasmic proteins. We found that the $d s b A$ mutant additionally deprived of the functional $h t r A$ gene showed markedly higher sensitivity to DTT at $30{ }^{\circ} \mathrm{C}$ compared to the parental strain. This phenotype was suppressed only partially by the overproduction of the proteolytically inactive HtrAS210A (Fig. 1). This result indicated that the chaperone activity did not play a dominant role in the efficient protection of the cells and that as well as this, the proteolytic activity was required for the bacteria to survive.

In order to gain a greater understanding of the significance of the proteolytic activity of HtrA at low temperatures, we examined its influence on the activity and cellular content of AP. Native AP contains two S-S bonds, which are introduced by DsbA. The non-native forms of AP were shown to be substrates for HtrA (Akiyama et al., 1992). At $30{ }^{\circ} \mathrm{C}$, in strains containing the functional DsbA/DsbB system, AP showed high activity, not affected by the presence of HtrA (Fig. 3a, c). In contrast, in the $d s b A$ background, AP activity was hardly detectable in the cultures expressing the proteolytically active HtrA. This result was quite surprising, as Spiess et al. (1999) reported that at $28{ }^{\circ} \mathrm{C}$ the presence of HtrA markedly improved the yield of active $\alpha$-amylase MalS, its other natural substrate. To exclude the possibility that the observed degradation of AP was the result of too high a temperature, we repeated the experiment at $25{ }^{\circ} \mathrm{C}$. Again, we observed the lowering of AP activity in the presence of the wild-type HtrA, accompanied by a decrease in the amount of AP (Fig. 4). The overproduction of proteolytically inactive HtrAS210A did not affect either AP activity or content; thus, we assumed that the decrease of the cellular AP level was due to the proteolytic activity of $\mathrm{HtrA}$ and not to the presentation of the unfolded AP to other proteases by HtrA. This result strongly contrasts with data presented by Spiess et al. (1999), who showed that the expression of HtrAS210A in a htrAdsbA background increased the activity of MalS more than tenfold. The folding of AP is not a simple process. Native AP is a dimer containing two S-S bonds formed between two nonconsecutive Cys residues. Its spontaneous folding is very inefficient, as it comprises oxidation, isomerization and oligomerization steps. The complexity of the folding process might be the reason for the lack of effect of HtrA chaperone activity on AP maturation. A similar observation was presented in the works of Misra et al. (2000) and CastilloKeller \& Misra (2003). These authors found that overproduced, mutated subunits of outer-membrane porins OmpF or OmpC were sequestered by HtrAS210A but their assembly into active oligomers was not improved. We expect that when the folding of a protein is too complex, HtrA is not able to perform it on its own and other folding factors are engaged in the process. Under stressful conditions the deficiency of chaperones and other folding factors frequently occurs. In such situations the unfolded polypeptide will most probably be degraded.

The degradation of AP in the presence of wild-type HtrA was also observed at $20{ }^{\circ} \mathrm{C}$, a temperature at which the proteolytic activity of HtrA has not so far been reported. How did HtrA become active at such a low temperature? As revealed by the crystal structure of HtrA, the lack of proteolytic activity at low temperatures results mainly from interactions of three loops - L1, L2 and LA - that block access to the active centre, keeping it in an incorrect conformation (Krojer et al., 2002). Within the LA loop there is a disulfide bridge (C57-C69), which is introduced by DsbA (Skorko-Glonek et al., 2006). The presence of this $\mathrm{S}-\mathrm{S}$ bond was shown to contribute to the maintenance of protein stability (Skorko-Glonek et al., 2003). HtrA deprived of the S-S bond (either by mutation or by reducing agents) was prone to autocleavage even at $4{ }^{\circ} \mathrm{C}$ (our unpublished observation). Therefore we considered that the proteolytic activity observed at low temperatures might be due to a reduction of the S-S bond within the LA loop. This assumption was further confirmed by experiments with the cysteineless HtrA mutant $(\Delta$ CysHtrA; equivalent of $100 \%$ reduced $\mathrm{HtrA}$ ). $\Delta$ CysHtrA degraded AP more efficiently than the wild-type HtrA at a temperature range of $20-30{ }^{\circ} \mathrm{C}$. The differences in cleavage efficiency between $\Delta$ CysHtrA and wild-type HtrA were most pronounced at $20{ }^{\circ} \mathrm{C}$. In these conditions wild-type HtrA degraded very low amounts of AP and did not affect AP activity in cellular lysates, whereas $\Delta \mathrm{CysHtrA}$ cleaved the majority of AP (Fig. 4). These results were consistent with the fact that the wild-type HtrA was not fully reduced under experimental conditions (Fig. 5). 
How could the reduction of the LA loop influence the activation mechanism of HtrA? As was mentioned in the Introduction, during the activation process the LA loop must leave the opposing subunit. The reduction of the S-S bond within the LA may increase the loop's flexibility and this in turn may facilitate the disruption of the LA-L1-L2 loop trio. This assumption is supported by the observation that the HtrA mutant lacking a part of the LA loop (amino acids 39-78) was more active proteolytically than the wildtype protein (Jomaa et al., 2007). Whether the reduction of the disulfide bridge alone is sufficient for the activation of HtrA we do not know. It is also possible that the allosteric mechanism of HtrA activation is involved in this process. There is experimental evidence that a peptide, located in the C-terminal region of pilin subunits, acts as an activator of HtrA protease but is not cleaved by HtrA. The carboxyterminal peptide of PapG, KSMCMKLSFS, greatly enhances degradation of the substrate (10-20-fold) (Jones et al., 2002). The binding occurs most probably at the PDZ1 domain (Iwanczyk et al., 2007) and in this case we expect that the reduced LA loop could more readily respond to signals coming from PDZ domains.

$\beta$-Casein, a commonly used non-native protease substrate, is not cleaved by HtrA at low temperatures (Spiess et al., 1999 and our unpublished data). AP and MalS, natural substrates of $\mathrm{HtrA}$, were efficiently cleaved at $20{ }^{\circ} \mathrm{C}$. These proteins, in contrast to $\beta$-casein, contain S-S bonds in their native state and were reduced prior to cleavage by HtrA. It is possible that the presence of exposed thiol groups of a substrate is an additional recognition/activation signal for HtrA. Under physiological conditions extracytoplasmic proteins do not contain free $\mathrm{SH}$ groups; thus, their presence might be a signal of disturbances in protein structure. The redox state of HtrA depends on the proper functioning of the DsbA/DsbB oxidoreductase system and on the redox potential of the growth medium. The presence of reducing compounds in the environment disturbs formation of disulfide bonds; hence, improperly folded proteins can accumulate in the cell envelope. Under anaerobic conditions this phenomenon might be even more pronounced due to the lack of air oxidation. One can postulate that under reducing conditions HtrA becomes activated and recognizes proteins lacking $\mathrm{S}-\mathrm{S}$ bonds. This hypothesis, however, requires further experimental verification.

The temperature-independent activation of the proteolytic activity of HtrA is likely to play an especially important role in bacteria residing in the external environment. HtrA was shown to be involved in the cellular responses to various stress conditions. These include oxidative stress, presence of reducing agents, changes in the osmolarity of the environment and alkaline $\mathrm{pH}$. So far, the majority of research on HtrA-dependent stress response has been conducted at $30{ }^{\circ} \mathrm{C}$ or at higher temperatures. Little is known about the involvement of HtrA in the stress response at low temperatures. However, HtrA participates in the activation of the two-component signal transduction pathway CpxAR, which induces a set of proteins engaged in the response to alkaline $\mathrm{pH}$, osmotic upshift, copper ions, detergents, changes in the composition of the inner membrane and disturbances in pili biogenesis, and in the response to surface sensing via NlpE, therefore in biofilm formation (reviewed by Dorel et al., 2006). E. coli may encounter all these stresses in the outside environment at various temperatures, including those below $30{ }^{\circ} \mathrm{C}$.

In conclusion, our results shed new light on the properties of HtrA protease at low temperatures. We have shown, apparently for the first time, that HtrA may act as a protease at $20{ }^{\circ} \mathrm{C}$ and that this ability can be achieved via reduction of the $\mathrm{S}-\mathrm{S}$ bond within the LA regulatory loop. Further experiments are required to explain the principle of the redox-state-dependent activation of HtrA.

\section{ACKNOWLEDGEMENTS}

We are grateful to M. Ehrmann for the generous gift of the pCS13 plasmid.

\section{REFERENCES}

Akiyama, Y., Kamitani, S., Kusukawa, N. \& Ito, K. (1992). In vitro catalysis of oxidative folding of disulfide-bonded proteins by the Escherichia coli dsbA ( $p p f A$ ) gene product. J Biol Chem 267, 22440-22445.

Bardwell, J. C., McGovern, K. \& Beckwith, J. (1991). Identification of a protein required for disulfide bond formation in vivo. Cell 67, 581-589.

CastilloKeller, M. \& Misra, R. (2003). Protease deficient DegP suppresses lethal effects of a mutant OmpC protein by its capture. J Bacteriol 185, 148-157.

Clausen, T., Southan, C. \& Ehrmann, M. (2002). The HtrA family of proteases: implications for protein composition and cell fate. Mol Cell 10, 443-455.

Dorel, C., Lejeune, P. \& Rodrigue, A. (2006). The Cpx system of Escherichia coli, a strategic signalling pathway for confronting adverse conditions and for settling biofilm communities? Res Microbiol 157, 306-314.

Hiniker, A. \& Bardwell, J. C. A. (2004). In vivo substrate specificity of periplasmic disulfide oxidoreductases. J Biol Chem 279, 12967-12973.

Iwanczyk, J., Damjanovic, D., Kooistra, J., Leong, V., Jomaa, A., Ghirlando, R. \& Ortega, J. (2007). The role of the PDZ domains in Escherichia coli DegP protein. J Bacteriol 189, 3176-3186.

Jakob, U., Muse, W., Eser, M. \& Bardwell, J. C. A. (1999). Chaperone activity with a redox switch. Cell 96, 341-352.

Jomaa, A., Damianovic, D.., Leong, V., Ghirlando, R., Iwanczyk, J. \& Ortega, J. (2007). The inner cavity of Escherichia coli DegP protein is not essential for molecular chaperone and proteolytic activity. J Bacteriol 189, 706-716.

Jones, C. H., Dexter, P., Evans, A. K., Liu, C., Hultgren, S. J. \& Hruby, D. E. (2002). Escherichia coli DegP protease cleaves between paired hydrophobic residues in a natural substrate: the PapA pilin. J Bacteriol 184, 5762-5771.

Kishigami, S., Akiyama, Y. \& Ito, K. (1995). Redox states of DsbA in the periplasm of Escherichia coli. FEBS Lett 364, 55-58.

Krojer, T., Garrido-Franco, M., Huber, R., Ehrmann, M. \& Clausen, T. (2002). Crystal structure of DegP (HtrA) reveals a new proteasechaperone machine. Nature 416, 455-459. 
Krojer, T., Sawa, J., Schafer, E., Saibil, H., Ehrmann, M. \& Clausen, T. (2008). Structural basis for the regulated protease and chaperone function of DegP. Nature 453, 885-890.

Laemmli, U. K. (1970). Cleavage of structural proteins during the assembly of the head of bacteriophage T4. Nature 227, 680-685.

Lipinska, B., Fayet, O., Baird, L. \& Georgopoulos, C. (1989). Identification, characterization, and mapping of the Escherichia coli $h$ trA gene, whose product is essential for bacterial growth only at elevated temperatures. J Bacteriol 171, 1574-1584.

Misra, R., Castillo Keller, M. \& Deng, M. (2000). Overexpression of protease-deficient $\mathrm{DegP}_{\mathrm{S2} 10 \mathrm{~A}}$ rescues the lethal phenotype of Escherichia coli OmpF assembly mutants in a $\operatorname{degP}$ background. J Bacteriol 182, 4882-4888.

Missiakas, D. \& Raina, S. (1997). Protein misfolding in the cell envelope of Escherichia coli: new signaling pathways. Trends Biochem Sci 22, 59-63.

Munson, L. \& Fall, R. R. (1978). Purification and characterization of Escherichia coli alkaline phosphatase. Biochem Educ 3, 100-105.

Oberfelder, R. (1993). Detection of proteins on filters by enzymatic methods. In Methods in Nonradioactive Detection, pp. 83-85. Edited by G. C. Howard. Norwalk, CT: Appleton \& Lange.

Raina, S., Missiakas, D. \& Georgopoulos, C. (1995). The rpoE gene encoding the $\sigma^{\mathrm{E}}\left(\sigma^{24}\right)$ heat shock sigma factor of Escherichia coli. EMBO J 14, 1043-1055.

Sardesai, A. A., Genevaux, P., Schwager, F., Ang, D. \& Georgopoulos, C. (2003). The OmpL porin does not modulate redox potential in the periplasmic space of Escherichia coli. EMBO J 22, 1461-1466.

Savageau, M. A. (1983). Escherichia coli habitats, cell types, and molecular mechanisms of gene control. Am Nat 122, 732-744.

Schlieker, C., Bukau, B. \& Mogk, A. (2002). Prevention and reversion of protein aggregation by molecular chaperones in the E. coli cytosol: implications for their applicability in biotechnology. J Biotechnol 96, $13-21$.

Skorko-Glonek, J., Krzewski, K., Lipińska, B., Bertoli, E. \& Tanfani, F. (1995). Comparison of the structure of wild-type HtrA heat shock protease and mutant HtrA proteins. A Fourier transform infrared spectroscopic study. J Biol Chem 270, 11140-11146.

Skorko-Glonek, J., Lipinska, B., Krzewski, K., Zolese, G., Bertoli, E. \& Tanfani, F. (1997). HtrA heat shock protease interacts with phospholipid membranes and undergoes conformational changes. J Biol Chem 272, 8974-8982.

Skorko-Glonek, J., Zurawa, D., Kuczwara, E., Wozniak, M., Wypych, Z. \& Lipinska, B. (1999). Escherichia coli heat shock HtrA protease participates in the defense against oxidative stress. Mol Gen Genet 262, 342-350.

Skorko-Glonek, J., Zurawa, D., Tanfani, F., Scirè, A., Wawrzynów, A., Narkiewicz, J., Bertoli, E. \& Lipinska, B. (2003). The N-terminal region of HtrA heat shock protease from Escherichia coli is essential for stabilization of HtrA primary structure and maintaining of its oligomeric structure. Biochim Biophys Acta 1649, 171-182.

Skorko-Glonek, J., Sobiecka-Szkatula, A. \& Lipinska, B. (2006). Characterization of disulfide exchange between DsbA and HtrA proteins from Escherichia coli. Acta Biochim Pol 53, 585-589.

Souza, V., Castillo, A. \& Eguiarte, L. (2002). The evolutionary ecology of Escherichia coli. Am Sci 90, 332-341.

Spiess, C., Beil, A. \& Ehrmann, M. (1999). A temperature-dependent switch from chaperone to protease in a widely conserved heat shock protein. Cell 97, 339-347.

Wickner, S., Maurizi, M. R. \& Gottesman, S. (1999). Posttranslational quality control: folding, refolding, and degrading proteins. Science 286, 1888-1893.

Edited by: T. Abee 